\title{
APPLICATION OF LEAN METHODS IN A LIFE OF A PHARMACEUTICAL COMPANY
}

\author{
Orsolya Szabó \\ Student, Szent István University, Faculty of Economics and Social Sciences, Logistics \\ Management MSc, \\ E-mail: szaborsi12@gmail.com
}

\begin{abstract}
Nowadays the very changeable pharmaceutical trends, the political, economical and global effects, the appearance of new -mainly chinese and indian- competitors and companies established and/or stopped throughout fusions and acquisitions want to get more and more share from the global cake of pharmeceutical industry, in this way securing their stable subsistence. How can be a Hungarian subsidiary attractive for a French multinational company? The answer for the question in our case: with the help of Lean. To meet the very variable customer's demand we need to find the optimum point of the total value stream. It is very important to eliminating, re-thinking and standardizing all the activities, flow steps and bad habits which not contributing to added value of the product or service from the customer point of view. The reduction of production, logistics and quality conroll costs have a stressed role in the company strategy. To reach these goals we have to decrease the followings: the production lead time, the changeover times, charging the environment, the plant cycle time, the inventories and the number of quality controll tests. Production in pull system, applying the Kanban and supermarket methods can also help to get the point.

The aim of my study - based on my own data collection - is to define the scope of the VSM cycle time sessions, compare and analyse the results of the present and future state of the observed product family from different aspects such as: Will the total plant cycle time decrease by (at least) $30 \%$ ? Will the ratio of value added activities reach the industrial average of $10 \%$ ?
\end{abstract}

Keywords: pharmaceutical industry, Lean, value stream, added value, cost reduction JEL classification: $L 650$

\section{Introduction}

Lean is a Japanese term and thinking method. The meaning refers to the content i.e. rationalization of processes and eliminating all the unnecessary activities.

During the economic crisis many companies turn to the Lean. There are numerous examples for the reason for existance of the application of it in the Western world. It helps for seeking the way out of the crisis for certain companies.

Let's see the Lean from other point of view. If we investigating the economic processes and its moving springs from helicopter view, firstly we need to focus on Hungary. Often says that there is a cheap and well-educated workforce in the Eastern-Central European countries, and businesses can operate beside relatively low costs. 
Sometimes multinational companies decide that they will not launch subsidiary in Hungary just after the finalization of the feasibility study. The reason of this in one hand is the EU membership. Companies cannot influencing these outer circumstances, in this way they need to adapt to the given situation in order to remaining in the market competition.

I would like to emphasize the actuality and importance of Lean application, because those companies which can react the fastest and most flexible way and can be cost effective win the competition for the customers.

The pursuit of perfection and request for the perfection by the customers do not contains solely the product, but they expect the perfect operation of the company. Lean is a tool for these kind of requests.

How can a Hungarian subsidiary be attractive for a French multinational company? The answer for the question is also Lean in our case. With this thinking method our company can reacts flexible for the changings.

It has proved that the analysed - more than 50 years old - product's technology, processes have additional opportunities which will be exploit with the following Lean tools: 5S (Seiri: choosing and separating, Seiton: Tidying up, Seiso: to clean up, Seiketsu: to standardize, Shitsuke: to sustain), SMED (Single Minutes Exchange of Die), Kanban, VSM (Value Stream Mapping) and VMI (Vendor Managed Inventories).

\section{Material and methods}

In my study I am going to investigate that will the plant cycle time decreasing (at least) by $30 \%$ of the observed product family and will the ratio of the value added activities reach the industrial average of $10 \%$ ?

I collected actual data between 2012-2014 and based on this period I made a comparative analysis with the present and future state of the value stream mapping regarding the whole routes of material flowing. During the study I calculated with the average values of the period. Because the campaign production the collected data needed to clean, in this way the extreme values were eliminated. With the 'door-to-door' probe, the results of every flow steps were commented, this securing the transparency and distinctness of the whole process.

The aim of my study is the data level definition of the individual process steps of VSM cycle times based on my data collection, the comparison and evaluation of the results of the two anaysed periods and finally taking suggestions for further development possibilities.

\section{Professional literature fundamentals}

Lean is often used in the company language. It can be describe in Hungarian as the usage of common sense.

Of course numerous professionals have written their point of view in connection with Lean. In this part of the study I am going to present some of them.

According to Mary and Tom Poppendieck 'Lean is a mindset - a mental model of how the world works. We start with two fundamental questions: What is the purpose of the business? 
What kind of work systems are best for accomplishing that purpose?' (PoppendieckPoppendieck, 2013.)

In an other approach it is need to define firstly what is the value for the customer? A long as we do not identify this the company produces or provides vainly. If they do not produce the requested quantity and/or quality etc. the perfection and precision does not matter, they produce waste.

The definition of waste (in Japanese: muda) is the following: '... every human activity that using resources, but does not generate value: defects need to repair, production of articles remaining on stock, unnecessary processing steps, aimless moving of people and goods, delays because of waiting for the finalization of the previous process step and goods and/or services that do not meet the customers requests.' (Womack - Jones, 2009.) In one word every process which consumes costs, but there is no added value for the customer.

Andrea Chiarini devided the types of wastes for the following categories:

- 3 'MU' (Muda: more capacity than workload, Mura: capacity that swings around the fixed target, Muri: more workload than capacity)

- 4M (Man, Material, Machine, Method of work), which is a traditional Japanese TQM (Total Quality Management) approach, often referring to Ishikawa or Fishbone graph.

- 7 wastes in the Toyota Production System: overproduction, inventory, defectiveness, transportation, overprocessing, motion and waiting.

Martichenko (2013) compares the Lean journey to his daughter's first day in the elementary school. In his opinion the key element of the Lean is simplicity. Plan! Do! Check! Act! He is considering to mention that Lean is not a tool but method of thinking. Despite of this in case of lot of companies there is not enough time to pick it up. As a result of this they cannot thinking deeply about how can they operate, or how do their activities, processes better and more effective? They much more focus on How? instead of Why?. Martichenko (2013) considers the sustainability of Lean questioning this two questions in the appropriate time.

According to Taichii Ohno - one of the 'father' of Toyota - Lean gives the opportunity for the better results which need less and less human-, material- and machine resources in between maximizing the customer service and satisfaction.

William M. Feld in his Lean Manufacturing book gives the following definition for the holistic view of Lean. 'The concept of holistic is meant to imply the interconnectivity and dependence among a set of five key elements. Each individual element is critical and necessary for the succesful deployment of a lean manufacturing program, but no element can stand alone and be expected to achieve the performance level of all five elements combined.' (Feld, 2001.)

Hereinafter I would like to briefly mention the professional definitions of the value, the value stream and the value stream mapping.

Beside reducing the wastes it is important to define what is the value for the customer. 'Only the final user can decide what is count for value and it is essential to talking about value if a certain product (good or service or often the mix of them) can meet the customer demand in the appropriate time and price. The value is creating by the manufacturer.' (Womack - Jones, 2009.) 
To put the process approach thinking forward it is necessary to create the value stream. 'The value stream contains all the operations that necessary for driving the given product (goods and/or services of often the mix of them) throughout the three most important leadership tasks of a company: from the idea to the detalied shape- and technical design, from starting the production to the problem solving and the phisical process from the raw material to the final product that can marketable to the customer. The next step of Lean thinking is the identification of the value stream of each products (in certain cases all production families).' (Womack Jones, 2009.)

With the help of preparing the value stream map we can get a clear present state vision not only about the workflow steps one by one, but globally for the whole product family. With VSM we can optimizing the processes, which tracking the product from the supplying of raw materials to the delivery of final product to the customers. VSM also secures the traceability of the material and information flows and helps to create the future state map.

'It is more effective than such kind of quantitative methods regarding non value added steps, lead times, distance of delivery and inventory. The value stream mapping is such a qualitative method which helps to define the detailed conditions of the operation driven by process method. Numbers are useful to create the feeling of pressure and good for the before-after type of measures, but the value stream mapping helps to define exactly how can affect these numbers. (Rother - Shook, 2012.)

Gyenge at al. (2015) wanted to show that not only the classic mass production companies follow the example of Lean management but also small manufacturing and service companies. The reason for Lean's 'popularity' is that its adaption improves several dimensions of creating customer value at the same time. The introduction of Lean management is about more than applying Lean tools or even concepts; it improves the entire organization, regardless whether the given result is called Lean or not.

\section{Results and discussion}

\section{Present state of API_1 product family}

The aim of the study was the analysis of the total plant cycle time of API_1 product family and the minimization of PCT in the future state in order to the fastest customer service. The most exact drawing of the present state is necessary for the reliable future state.

The scope of data collection and the observation were the cycle times (electronic data, plant capacity data, Batch Record data), the relaunch time, the inventories, the QC analitical lead time and the number of IPC (In Process Controll) samples. I used data primary from our ERP (Enterprise Resource Planning) and QC systems and beside these I randomly selected n number of Batch Records which contains all the controlled parameters. In this way I tried to eliminate the gap between the reality and electronic systems. These gaps come from technical problems, execution of special technical operations and some extreme parameters take into the system intentionally. 
In the 1st table I would like to present all the logical steps of API_1 product family from the production to the delivery with the help of the own collected and evaluated data. For the better understanding of data I applied the following definitions for the different process steps:

- I calculated the production lead time based on the period from the first material tracking by BCR (Bar Code Reader) or manually to the first completion transaction date of the batch.

- The administrative time is the distinction of the first completion transaction date and the date of sample taking.

- The quality leadtime contains the period from sample taking to the releasing date of the batch. (Here necessary to mention that the QC works in one shift and there is no dedicated equipment for every product.)

- The logistical time practically represents the time spending on stock of a given batch from the quality releasing to the CEP (Central European Platform - SAP module) transfer, or (in case of intermediates) the date of first consumption by the next production step. In case of IPC analysis the logistical period contains the first completion transaction date of the batch to the first consumption by the next production step.

- The CEP time means the date of first CEP transaction to the date of accounting of the delivered batches.

As self-controll I randomly selected $n=20$ Batch Records in order to compare the electronic data to the actual data recorded by colleagues in the plant.

1. table API_1 VSM highlight 2012-2013.

\begin{tabular}{|c|c|c|c|c|c|c|c|}
\hline Description & $\begin{array}{l}\text { Production } \\
\text { leadtime }\end{array}$ & $\begin{array}{c}\text { Administrative } \\
\text { time }\end{array}$ & Quality leadtime & Logistical time & CEP time & $\begin{array}{c}\text { Key-raw } \\
\text { maiteriiall on } \\
\text { stock }\end{array}$ & $\sum$ 2012-2013. \\
\hline API 1 & 2,4 & 0,5 & 13,6 & 28,5 & 5,0 & & 50,0 \\
\hline INT 5 & 1,7 & & & 4,3 & & & 6,0 \\
\hline INT_4 & 3,7 & 0,9 & 3,8 & 19,8 & & & 28,2 \\
\hline INT_3 & 4,0 & & & 1,9 & & & 5,9 \\
\hline INT_2 & 4,5 & & & 61,0 & & & 65,5 \\
\hline INT 1 & 3,3 & & & 5,7 & & & 9,0 \\
\hline Key-raw material_1 & & & & & & 84,4 & 84,4 \\
\hline Total (days) & 19,6 & 1,5 & 17,4 & 121,2 & 5,0 & 84,4 & 249,1 \\
\hline
\end{tabular}

Source: own table, 2015.

It is evidence from the table that the total plant cycle time of the present state takes 249,1 days from receiving the key-raw material to the delivery of the product. From this total time our value added time was 21,6 days which is $8,7 \%$.

In order to fully evaluate these results we need to know the following productional specialities, such as:

- the production line is used by an other product family (API_2) which contains two steps,

- both API produced in campaigns,

- certain production steps do not occupy the whole production line in the same time, in this way overlapping is enable,

- from technological and economical point of view both API and its intermediates produced in continuous shifts,

- API_1 has approximately 10 different domestic and foreign customers and it is sold quantities from $\sim 100 \mathrm{kgs}$ to 10 tons weekly frequency, 
- API_2 has one intercompany customer so the ordered quantity and its calendarization (4-5 orders per year) is reliable (this is the pole of the yearly scheduling of this production line),

- the CSL (Customer Service Level) $\geq 98,5 \%$ is defined centrally by the company.

After that, we designed the future state which contains all the goals, achievable and developable opportunities and suggestions.

\section{Future state of API_1 product family}

In the previous part of the study the team gave ideas for elimination of wastes, presented suggestions and new ideas. As a result of these the future state was created which aim was such kind of value stream in which:

- beside the opportunities pull system will be introduced,

- minimizing the inventory level taking into account the customer service level and campaign production, applying Kanban and supermarket for securing API supply,

- decreasing the setup and changeover times with the application of SMED,

- reduction of phisical moving of raw materials and intermediates,

- -beside regulatory and analitical directions we study the opportunity of decreasing the number of specific tests and take into account the possibility of follow-up tests.

Over these general goals, the team wanted to reach the following changes as a result of the simplyfied future state:

- decreasing the quality lead time of INT_2 from 3,1 days to 1 day, and lightening the inventory level of it from 61 days to 5 days;

- easing down the quality lead time of INT_3 from 3,8 days to 0,1 day and introducing the Kanban;

- cutting down INT_4 quality lead time also to 0,1 day instead of 3,4 days, regarding its inventory also introducing Kanban (it means -19 days stock), at the most 1 day inventory is enable;

- introducing Kanban in case of INT_5, which means -4,3 days of stock,

- reducing the quality lead time of API_1 to 5 days and minimizing the inventories (3 days) with application of VMI;

- achieving the following changeover times (API_1 $\rightarrow$ API_2 from 240 hours to 60 hours, API_2 $\rightarrow$ API_1 from 139 hours to 8 hours);

- cutting the purchasing lead time of the key-raw material and studying the possibility of supplying from other source as well as boosting up the production of INT_2 with the enlargement of a production equipment (-8 hours lead time);

- common workshop with the two other Hungarian subsidiaries in connection with VMI introduction;

- defining the total plant cycle time of the future state (105 days).

In the 2nd table you can see the results of 2014 after the developing and realization of action plans. 
2. table API 1 VSM highlight 2014.

\begin{tabular}{|c|c|c|c|c|c|c|c|c|c|}
\hline Description & $\begin{array}{l}\text { Production } \\
\text { leadtime }\end{array}$ & $\begin{array}{c}\text { Administrative } \\
\text { time }\end{array}$ & $\begin{array}{l}\text { Qualiity } \\
\text { leadtiinne }\end{array}$ & Logiesticall timme & CEP timne & $\begin{array}{c}\text { Key-raw } \\
\text { matterial on } \\
\text { stock }\end{array}$ & $\sum 2014$. & $\underset{2013 .}{\sum 20112}$ & difif \\
\hline API_1 & 1,4 & $-0,2$ & 13,6 & 26,6 & 4,3 & & 45,7 & 50,0 & $-4,3$ \\
\hline INT_5 & 1,8 & & & & & & 1,8 & 6,0 & $-4,2$ \\
\hline INT_4 & 4,1 & $-1,1$ & 3,9 & 5,7 & & & 12,6 & 28,2 & -156 \\
\hline INT_3 & 1,8 & & & 3,0 & & & 4,9 & 5,9 & $-1,1$ \\
\hline INT_2 & 4,5 & & & 64,4 & & & 68,9 & 65,5 & 3,4 \\
\hline INT_1 & 14 & & & 98 & & & 11,3 & go & 2,3 \\
\hline Key_raw material_1 & & & & & & $5 i 1,7$ & 51,7 & 84,4 & $-32,7$ \\
\hline Total (days) & 15,0 & $-1,3$ & $17 s^{5}$ & T08,6 & 43 & $5, Z, Z$ & 196,8 & $249, e$ & $-52,2$ \\
\hline
\end{tabular}

Source: own table, 2015.

The most craggy change is the dropping of the total lead time by 52 days. Forthcoming I would like to present the contents of the approximately two months of decrease.

The total production lead time of the production line is less by nearly 5 days, which thanks to the result of the technical and technological developments. From my point of view - as a production planner - always has a key role such kind of results, because faster production gives the opportunity to reduce the imbalancing of our human and machine capacities, by the way in case of growing customer demand we can rise our activities in exchange for our free capacities.

Thanks to SMED workshops we reached the awaiting drop of changeover times regarding the two APIs and its intermediates on the same production line. This results also significant decreasing between the changeover time of the products.

The negative values of the administrative time means that the sample taking was just earlier than the completion of the working order. In case of API_1 the two occassions were almost at the same time, while in case of INT_4 the sample taking was one day earlier than completion of WO. This process is not important neither in the present nor in the future state.

There were not changes in quality lead times. In case of API_1 the 5 working days mean that in case of urgency the material can controlled within this time, but beside the controll of all other active product ingredients and intermediates it takes an average of 13,6 days. From this 13,6 days the QC produces added value (the effective manual work by QC ananlitical assistant) only on 2 days.

The logistical time reduced by $\sim 12$ days in case of INT_5 and INT_4 thanks to the implementation of Kanban, in other hand in case of INT_2 there was a slight increase of days on stock. There was not a radical rising, because the logistical time of the whole production family was reduced, but it is visible that we have not reached the aimed inventory cutting so far. API 1 time of inventory did not decreased so much and the reason of this that VMI introduction was in Sept 2014, after the analysed period. So the actual effect for the logistical time will be known by us only after the next follow up workshop.

Although there is no results of VMI in connection with the logistical time, but we have obtained the most valuable achievement with this tool. This was the inventory decreasing one-off by $\sim 320$ million HUF. This was also the gaining of creation of API_1 value stream and application of VMI in case of our two main domestic customers.

The biggest saving came from the stock keeping time of the key-raw material. We ordered both from the US and the Hungarian supplier, in this way we managed to eliminate the mono supplier situation in 2014. The raw material cycle time reduced by almost one month thanks to the more exact scheduling of our demand. 
These factors together contributed the drop of the total plant cycle time of API_1 product family by 52 days. We created added value on 17 days from 197 days, this means 8,6\% VAT ratio.

My hipothesis failed from the point of view of cycle time reduction which was only $21 \%$ despite of the introduced changes, developments in Sept 2014. In comparison with the 2013-2014 data the value added time of the whole process was $8,6 \%$ and $8,7 \%$ which did not reach the requested $10 \%$.

\section{Conclusion}

The implementation of action plans regarding quality are in progress, and some of them already have come true. These contain the reduction of number of IPC samples and want to decrease the quality lead time. Taking into account that the Quality Conroll working in one shift, I think that the realization of these goals will contribute the reduction of their human resource overloading.

The elimination of wastes origin from the unnecessary phisical moving of materials in the areas of warehouse and chemical plants implied the re-thinking and revising of the material handling, serving and consuming flows and processes. As a result of these we saved $\sim 1500-1600$ unnecessary movings, container cleanings, drum and container transportations during a year. As I mentioned in the professional part of the study one of the seven wastes is the redundant moving. This immediately procures an other which is the waiting. Waiting during the time while the consumable material arriving at the plant. I suggest the implementation of Kanban warehouse in the chemical plants (firstly in case of packaging materials) in order to solving this problem.

With the help of technological parameters the production lead time can reducing and saving energy, manufacturing and destruction costs.

Some of the listed action plans concerning the regulatory dossiers, so - as I mentioned before - the realization of these take a little more time. The technological innovations including the increase of productivity, gaining more human- and machine resources. In my opinion all these factors and action plans - over their positive effects on the competitiveness - boost us to reach new activities and suitable for the expansion of our present manufacturing possibilities.

Past the mentioned action plans and the knowledge of the results of the implemented ideas, I take the following suggestions in order to reach more and more progress:

- Reduction the average quality leadtime of API_1 from 13,6 days to 7 days.

- It is need to secure the key raw material supplying not only from the US source, but from the Hungarian too, in order to decrease the 3-4 months of purchasing leadtime.

- Key raw material supplying in VMI system by the Hungarian manufacturer.

- Better cohesion between data of ERP system and data of Batch Records. The starting point of the production scheduling is the reliable data regarding the production- and overlapping lead times which can decrease the danger of over, or under scheduling.

- Real online material tracking which can drop the discrepancies concerning inventories. In this way it can be eliminating that the raw material scheduling based on false inventory data.

- Fine scheduling of INT_2 in order to slack the 60 days stock keeping time. To reach the requested result it is need to cooperate closely with the Value Stream managers and with the Plant leaders, because the plant human resource is the bottle neck of the production scheduling. 


\section{References}

1. Feld, W. M. (2001.): Lean Manufacturing - Tools, Techniques, and How To Use Them, Boca Raton, FL, CRC Press, 3-6. p.

2. Gyenge B. - Szilágyi H. - Kozma T. (2015.): Lean Management in case of a Logistics Service Provider Company. JOURNAL OF CENTRAL EUROPEAN GREEN INNOVATION

(http://greeneconomy.karolyrobert.hu/sites/greeneconomy.foiskola.krf/files/upload/08 Gyengye_et_al_2.pdf) III.:(1) 119-134.p.

3. Martichenko R. O. (2013): Elemi LEAN - Mindent, amit a leanröl tudok, az elsö osztályban tanultam, LEI Magyarországi Egyesülete, 15-16., 39-40., 66-67. p.

4. Poppendieck, M. -Poppendieck, T. (2013.): The Lean Mindset - Ask the Right Questions, Massachusetts, Addison-Wesley, 3-9. p.

5. Rother, M. - Shook, J. (2012.): Tanulj meg látni - Az értékfolyamat-térképezés szerepe az értékteremtésben és a veszteség kiküszöbölésében, LEI Magyarországi Egyesülete, 1-3., 36-37., 40., 49-50. p.

6. Womack, J. P.- Jones, D. T. (2009.): Lean szemlélet, Budapest, HVG Kiadó Zrt., 21109. p.

\section{Used in intellectuality without reference}

7. Chiarini, A. (2013.): Lean Organization: from the Tools of the Toyota Production System to Lean Office, Springer-Verlag Italia

8. Liker J. K. (2008.): A Toyota-módszer - 14 vállalatirányítási alapelv, Budapest, HVG Kiadó Zrt.

9. Szegedi Z. - Prezenszki J. (2005.): Logisztika-menedzsment, Kossuth Kiadó

\section{Electronic sources - Used in intellectuality without reference}

10. CHINOIN Private Co. Ltd. -a Sanofi company- company brochure, presentations

11. http://www.leandesign.hu/item/1938-gyors-atallas-smed

12. Date of downloading: 16 Oct 2014.

13. http://www.leanthinking.info/TheToyotaWay.pdf

14. Date of downloading: 23 Oct 2014. 